\title{
12 \\ Avoiding the Global Financial Crisis in Australia: A policy success?
}

\author{
Stephen Bell and Andrew Hindmoor ${ }^{1}$
}

The puzzle that hasn't really been addressed is why, if we all operated within that same set of global rules, were countries like Canada largely untouched by the global financial crisis and Australia as well? Why, within countries that have been badly scarred, do some banks continue to do well, and why even in our own case where the financial system has coped better than most other countries, did some of our institutions still dip their toes into the more complex instruments?

- John Laker, former chairman, Australian Prudential Regulation Authority (ASIC 2009: 48)

\section{Staying out of harm's way}

The depth and spread of the international financial crisis that erupted in 2007-08 were not primarily due to the bursting of the credit-fuelled asset price bubble in the US housing market (Dodd and Mills 2008; Gorton 2008). Many countries suffered bigger real estate collapses than the United States without experiencing a financial crisis (Reinhart and Rogoff

\footnotetext{
1 This chapter, while written for the purposes of this volume, draws on interview material and analysis published in Bell and Hindmoor (2015: particularly Ch. 8).
} 
2009: 245). Instead, in the United States, the United Kingdom and parts of Europe, the crisis was largely driven by the scale of the exposure of banks and financial institutions to highly leveraged investments in US residential and commercial mortgage-backed securities. ${ }^{2}$ Such exposures reflected a historical reorientation of banking towards high-risk, highreturn banking and business models (Erturk and Solari 2007; Crotty 2009). The subsequent panic in financial markets and huge uncertainties regarding counterparty risks saw short-term credit markets become illiquid, placing further severe funding pressure on banks and other financial institutions, leading many to collapse.

Many accounts of the crisis have focused on general factors such as international financial imbalances, voluminous global liquidity flows, the growth of asset bubbles and the impact of the Basel regulations in encouraging off-balance-sheet banking activities (Acharya and Richardson 2009; Davies 2010). Other accounts have focused on national market conditions featuring high levels of bank competition and takeover threats that placed a premium on the pursuit of short-term profits, on light touch' national regulatory conditions (Turner 2009: 86-8) and on implicit bailout guarantees provided by governments and central banks (Ritholtz 2009). For his part, former governor of the Bank of England Mervyn King (2009: 10) has argued that 'unsustainable capital flows provided the fuel and an inadequately designed regulatory framework ignited the fuel' that blew up financial systems.

Missing in such generalised 'checklist' accounts is a focus on the highly variable comparative nature of bank performance prior to the crisis, as noted in the opening quote of this chapter by John Laker from the Australian Prudential Regulation Authority (APRA). Australia and Canada, for example, did not experience a major banking crisis, while the United States, the United Kingdom and many countries in Europe did. In these countries, banks' risk-assessment standards were relaxed, leverage and dependence on short-term funding grew and speculative trading in risky financial instruments was encouraged—eventually with disastrous results.

2 Mortgages were packaged into saleable financial assets (securities), with residential mortgage securities often referred to as residential mortgage-backed securities. 
There is an important causal logic at work here. If banks operating within 'the same set of global rules', to quote Laker, can behave so differently in a comparative sense, this means global conditions can only have operated as a permissive rather than a substantive cause of the crisis. The decision to trade in securitised assets (or not) was taken by individual banks and the bankers within them, in part reflecting banks' motives and in part reflecting variable national conditions in markets and regulation. We therefore need to focus on bankers as key agents, particularly the way in which prevailing ideas and institutional and governance arrangements shaped banking behaviour.

This chapter focuses on one facet of this wider comparative institutional puzzle: the performance of the four major Australian banks-Westpac, the Commonwealth Bank, the Australia and New Zealand Bank (ANZ) and the National Australia Bank (NAB). Because they depended in part on overseas wholesale funding to supplement their domestic deposits base, the Australian banks were not immune to the effects of the GFC and they suffered from the global credit squeeze following the collapse of Lehman Brothers in late 2008. Some smaller institutions could not obtain wholesale funding and failed, while the big four banks had their credit guaranteed by the government. Nevertheless, not one of the four banks had its credit rating downgraded and, by late 2009, four of the nine global banks with an AA credit rating from Standard \& Poor's were Australian (RBA 2009: 25). Moreover, aggregate pre-tax profit at these four banks fell only marginally, from $\$ 6.3$ billion in 2007 to $\$ 5.1$ billion in 2008 and $\$ 5.4$ billion in 2009 .

The big Australian banks did well because they remained focused largely on traditional banking practices and had limited exposure to the kinds of leveraged securities trading that challenged or devastated so many overseas banks. ANZ and NAB did accumulate some exposure in the years before the crisis, which resulted in losses. Although NAB lost about $\$ 1$ billion, such losses were relatively minor when compared with its overall balance sheet and the experiences of many overseas banks. True, the government stepped in and guaranteed the debts of the big banks in offshore funding markets, but no panic occurred in local financial markets, although bank share prices suffered for a period. Banks kept lending and money kept flowing through the economy. There were no mass foreclosures of homes the mortgages of which could no longer be paid. 
In this volume, a policy is assessed as successful when it: 1) demonstrably achieves highly valued social outcomes and a broad base of public and political support for these achievements; and 2) manages to sustain this performance for a considerable period even in the face of changing circumstances. These were achieved in Australia in this case, yet 'success' lay mainly in the achievement of a series of 'non-events'. Australia was one of a handful of OECD economies that did not experience a major breakdown in its financial institutions and avoided an economic recession during and after the crisis. Dodging the danger, the economy managed to maintain its remarkable run of continuous economic growth (at the time of writing, this has extended to a record-breaking 108 quarters and shows no signs of abating).

A key question is why the Australian banks did not succumb to the crisis and why they did not 'reinvent' (Erturk and Solari 2007) themselves in the decade before the crisis in the way that many banks in the United Kingdom and the United States did? This chapter outlines the performance of Australia's major banks and shows that they pursued a traditional 'boring but safe' business model based largely on commercial and mortgage lending. It is argued that in an era of 'global' finance, interactions by banks with national market and regulatory conditions were a key driver of Australian outcomes.

Yet, there was a considerable element of luck involved. In particular, a key reason the big Australian banks did not become much involved in the highly leveraged financial trading that was at the centre of the crisis overseas was that the local banks were making strong profits in traditional mortgage markets and because regulation had reduced banking competition-a key driver of the bank behaviour and risk-taking in the crisis-hit banks' overseas markets. The luck involved was due to the fact that the regulation that helped limit banking competition-especially the ban on takeovers within the banking sector (the so-called four pillars policy) — was in fact designed to strengthen banking competition by preventing bank takeovers. The four pillars policy insisted that the big banks could not be taken over, thus eliminating a key competitive pressure on the large banks - namely, the threat of a hostile takeover in the context of possible equity market displeasure if a given bank was assessed to be performing below par.

The events and outcomes recounted in this chapter do amount to a 'policy success', but this was largely inadvertent-an unintended consequence. This chapter is thus unlike many in this volume. In the case analysed here, an explicit policy was not designed and implemented to tackle a known 
problem. The financial crisis that overwhelmed the core financial markets in the United States and the United Kingdom and which rippled around the world was not anticipated, and certainly in Australia, the key four pillars policy in question was not aimed at saving the banks from the GFC; it had been initiated years earlier. Yet, by limiting a certain type of banking competition (notably, takeovers of the major banks), it helped limit competition and save the Australian banks during the GFC.

The chapter proceeds by first outlining Australian banking performance during the crisis. It then argues that a banking crisis in the early 1990s followed by the collapse of the insurance giant $\mathrm{HIH}$ in 2001 had a salutary impact on the banks and helped tighten their prudential regulation. However, by far the most significant factors in shaping bank behaviour were strong markets and profits in traditional banking activity, combined with the four pillars policy. We analyse these sources of banking resilience in terms of programmatic, process and political assessments, showing how key policies can sometimes inadvertently achieve 'policy success'.

\section{Australia's banking performance}

The big four banks which had come to dominate the Australian deposit base and mortgage sector experienced a booming market in the $1990 \mathrm{~s}$ and 2000s, with strong economic growth and rising house prices fuelling strong bank asset growth and very high rates of return on equity by world standards (Hawtrey 2009: 108). The big Australian banks also remained heavily dependent on traditional banking, with residential mortgages as a key source of income. Gross loans (mortgages and commercial loans) constituted, on average, 72 per cent of the assets of the four largest banks in 1999 and 70 per cent of assets by 2006. In the United Kingdom, by contrast, at the five largest banks, gross loans fell from 59 per cent of total assets in 2000 to just 48 per cent in 2007. Australian banks also largely eschewed the subprime mortgage market. The obvious contrast here is with the United States, where the banks were increasingly drawn into the subprime market (FCIC 2011: 67-82). Australia’s bank regulator, APRA, estimates that the

non-conforming housing loan market in Australia (the closest equivalent to the sub-prime market in the United States) accounted for only around 1 per cent of the mortgage market in mid-2007, compared to around 13 per cent in the United States. (quoted in RBA 2009: 18) 
Australian banks' impaired loan ratio was the lowest in the world in the runup to the GFC, at just 0.2 per cent of total loans outstanding in 2006, compared with 1.8 per cent in the United Kingdom and 2.3 per cent in the United States.

In addition, and most importantly, Australian banks were not heavily exposed to 'toxic' securities. Although traded securities rose to $\$ 20.2$ billion in 2007 among the four largest banks (based largely on sound local securities), traded securities still only constituted an average of 4.6 per cent of assets in 2007 (down from 4.8 per cent of total assets in 1999). By contrast, in the five largest UK banks, securities trading was so central it accounted for 56 per cent of pre-tax profits in 2006. Similarly, in the United States, banks such as Merrill Lynch were earning 55 per cent of their revenue from securities trading, while Lehman was earning 80 per cent of revenues from trading (McGee 2010: 128-9; FCIC 2011: 66). International banks were trying to sell US-originated residential mortgage-backed securities products in Australia but, compared with what was happening overseas, there was not much interest in such exotica from the big Australian banks. As the Reserve Bank of Australia (RBA 2010: 18) argued in its 2010 Financial Stability Review:

One of the reasons why the Australian banks' earnings have remained comparatively stable is that their business models were focused on domestic lending. As a result, they had relatively little exposure to the kinds of securities that were a significant source of losses in the North Atlantic countries worst affected by the crisis.

A former RBA board member, John Edwards (2008), has similarly argued that 'Australian banks do not engage in trading activities to the same extent as the major global banks. They are closer to the model of the traditional balance sheet.'

\section{Previous banking crises and lesson learning}

Despite avoiding the GFC in 2008, Australia did have previous 'form' when it came to financial crises and major economic downturns. The global recession of 1929 hit Australia hard, all but destroying the newly elected Scullin Labor Government. Policy paralysis resulted, and the depth and duration of the ensuing Great Depression left deep scars. The crisis of stagflation (high inflation plus recession) in the 1970s also received an initially muddled macroeconomic policy response, which saw a pattern 
of stop/go economic growth and two recessions-one in the mid-1970s and another in the early 1980s (Bell and Keating 2018). The post-1983 Labor Government introduced a new and more successful approach built around a wage accord with the unions. However, financial deregulation during the 1980s and the entry of foreign banks encouraged Australian banks to defend their market share through aggressive credit practices that led to a credit-fuelled asset price boom, especially in commercial property (Kelly 1992: 487-508; Bell and Keating 2018). Hence, financial deregulation and inept handling by the government and the RBA saw a credit explosion and a commercial property boom that eventually ended with high interest rates as a control mechanism and an inadvertent policyinduced recession in the early 1990s. Financial deregulation had been aimed at letting markets play a greater role in the governance and operations of the financial and banking system. But this market perspective tended to limit or eschew concerns about 'systemic risk' in the system-marked by the buildup of doubtful debt and speculative activity in asset markets, especially, as it turned out, in commercial property markets.

This lack of oversight was a big policy mistake, as was the policy-induced recession. Senior journalist Max Suich (1991: 16) offered the following observations:

The Reserve Bank of Australia must be judged to have been asleep at the tiller ... The RBA, which during regulation had firm control of the banks, changed from nanny to couch potato, issuing instructions but taking little intelligent interest in how they were being observed—not least where the quality of bank lending was concerned.

The policy-induced recession that quelled the financial boom was deep and the recovery was weakened by slowness in reducing interest rates and a tardy fiscal policy response (Bell 2004a). Economic policymakers were convinced that the automatic stabilisers-government expenditures that increase automatically in a recession-would cut in, but this judgement turned out to be wrong and a 'hard landing' and a deep and costly recession in the early 1990s resulted. The upside was that lessons were learned and policymakers and central bankers became more determined to do whatever it took to try to ward off future recessions (Bell and Quiggin 2006). The outcome has been that, since the early 1990s, Australia has avoided the worst fallout from both the Asian Financial Crisis and the GFC, sustaining the longest expansion in the history of any capitalist economy. 
In policy process terms, monetary policy and regulatory lessons were also learnt. The RBA finally found a workable monetary policy approach based on flexible inflation targeting. It was also determined to try to avoid any further policy-induced recessions and handled the Asian Financial Crisis of the late 1990s adroitly by not raising interest rates and defying pressure on the currency by financial markets (Bell 2005).

For their part, the banks were hit hard by the recession of the early $1990 \mathrm{~s}$ but were able to learn from such experiences. The boom and bust resulted in the failure of some smaller institutions and the near-implosion of one of the majors, Westpac (Carew 1997). ANZ also had some trouble. That crisis spurred institutional learning in the sector, which took the form of bankers developing a keener institutional memory of what had led to the crisis and what had gone wrong. It also took the form of feeding off this memory to develop a banking culture that had greater insight into potential risks and a greater degree of risk aversion. A former Westpac chief executive argues that 'one of the reasons things went so right' during the 2007-08 international meltdown 'is that they went so wrong in the 1980s and early 1990s' (quoted in Cornell 2009). Former bank chief economist John Edwards (2008) agrees: 'Sixteen years later the salutary lessons of Australia's last deep recession still influence the conduct of the major banks.' Edwards (personal communication) continues: '[A]n entire cohort of bankers was emptied out after [the] early 1990s and replaced with more cautious bankers.' Ian Harper, a member of the 1998 Wallis inquiry into Australia's financial system, comments that, during the 1990s:

inside the banks there was a titanic struggle between the investment bankers and the credit risk managers. It was a culture war. But throughout the period, the chief executives were old-style bankers; the tyre-kicking cautious bankers in the end swept aside those who were hungry for yield. (quoted in Colebatch 2009)

In an interview with the authors, Saul Eslake, a former chief economist at ANZ, said the trauma of the late 1980s and early 1990s crisis was important: '[T]here were plenty of people within ANZ who retained a very strong corporate memory of the fact that they almost went out the door in the early 1990s.'

Westpac's Bob Joss (quoted in ASIC 2009: 52) argues that 'Australian banks were ahead of the curve compared to other major banks around the world, and were early adopters of better risk management systems and practices'. David Morgan, who became Westpac's CEO in the 
late 1990s, pushed further reforms, institutionalising the 'risk/reward' committee, bringing together all the major risk managers and senior managers at the bank and enforcing a conservative culture. As Morgan (quoted in Cornell 2009) recalls: 'Westpac had a near death experience in 1992 ... We didn't forget it.' Similarly, APRA's John Laker (2009: 52) argues that there were 'enough reminders that good times come to an end for boards to stay focussed ... There was a whole generation of bankers who'd been burnt. That corporate memory was very important'.

As John Laker explained to the authors in an interview, this led 'to greater visibility and much greater punching power for risk management functions within the banks. This conservative culture is reflected in Westpac's attitude to the sorts of structured investment products that were regularly offered to the bank by overseas investment banks. As one insider commented:

$[\mathrm{O}] \mathrm{n}$ one occasion a note went around. Do we understand this product? Does it make sense to rely on the credit ratings agency? Do we know the underlying exposures? Do we have an appetite for the volatility we have seen in these things before? (quoted in Cornell 2009)

Clearly, the Australian banks were chastened, and lessons were learned from the late 1980s and early 1990s. But while a general lesson may have been learned among Australian bankers about risk and the potential for boom to turn to rapid bust, the specific lessons learned stemmed from the fragility of commercial property markets. These lessons were less relevant in dealing with the leveraged trading at the core of the 2008 crisis. As a senior Australian banker explained to us:

[O]bviously, for ANZ and Westpac, they were near-death experiences back in the early ' 90 s, and so that certainly set the risk at the time for banks in Australia. That said, a lot of the core earnings coming out of the early ' 90 s was around concentration risk, driven very much by an overexposure to commercial property. The Global Financial Crisis was not so much about such concentration risk.

In an interview with the authors, the NAB's Chief Economist, Alan Oster, said: ' $[\mathrm{A}]$ good chunk of the people dealing these things [securities] would have not remembered the 1990s or wouldn't have been employed in the bank in the 1990s.' Charles Goode, former chairman of the ANZ, agrees: 'I don't think there were many in the banks that had been through 1991 in 2007 ... also, [unlike the early 1990s] it was an imported crisis, like a disease from overseas' (cited in Bell and Hindmoor 2015: 263). 
Explanations based essentially on interpretative agents and lesson-learning also beg questions about why UK and US bankers did not learn from their own earlier failures in the runup to 2007-09-for example, the failure of the Bank of Credit and Commerce International (in 1991), Barings Bank (in 1995) and the Equitable Life Assurance Society (in 2000) in the United Kingdom or, in the United States, the savings and loans debacle of the 1980s and the 1998 implosion of Long-Term Capital Management. A potential problem with invoking arguments about agency-based lessonlearning is that they fail to tell us enough about key agents and the circumstances and institutional conditions in which lessons are learned (or not). A key issue here is not just the way in which bankers were shaped by their immediate institutional history or context, but also by how they were shaped by wider institutional contexts. In the Australian context, we need to examine the impact of national regulatory conditions and how these shaped national market structures and conditions.

\section{The ramping up of banking prudential regulation}

There were important regulatory shifts. The RBA's lacklustre performance in bank regulation in the 1980s and early 1990s saw it stripped of responsibility for prudential regulation of the banks and financial institutions, in 1998, as part of recommendations from the Wallis inquiry (Bakir 2003). The task was instead given to the new Australian Prudential Regulation Authority (APRA). A further critical event was the 2001 collapse of the insurance giant $\mathrm{HIH}$, with losses of about $\$ 5$ billion. In the wake of this collapse, APRA took a 'public lashing', according to Laker. Charles Littrell, an executive general manager at APRA, told the authors in an interview it was a 'huge jolt' to the organisation. The episode revealed a lack of regulatory alertness on the part of APRA. APRA's former chief executive Graeme Thompson observes that the regulator was initially established under a broad approach designed to be non-intrusive and nonprescriptive (quoted in Clark 2009). A subsequent royal commission in 2003 encouraged APRA to adopt a 'more skeptical, questioning and, where necessary, aggressive' regulatory stance (quoted in Bell and Hindmoor 2015: 278). APRA subsequently adopted this approach and remained confident it had a robust prudential regulatory framework covering the banks, nonbanking institutions and superannuation funds. 
On the whole, APRA has established a close but authoritative relationship with the banks. It relies far less on black letter law enforcement of the kind found in jurisdictions such as the United States and more on supervision and suasion, trying to inculcate sound risk management principles among the banks. As APRA's Littrell puts it: 'We look more like a shepherd, if you will, not a traffic cop.' APRA's David Lewis (2008: 6) notes: 'It is a relationship that recognises that regulation works best when its goals and principles are internalised within the culture of the institutions being regulated.'

In the years after the HIH crisis and before the 2007-08 crisis, APRA intervened to reduce systemic risks in a number of ways. In 2002, it introduced a new risk assessment system designed to assess the unique risk profile of each regulated institution. Individual onsite and offsite reviews of the banks have been complemented since 2002 with a series of system-wide stress tests that have assessed banks' resilience to exogenous shock scenarios. APRA has also sought to minimise risk exposure through capital adequacy controls. First, APRA has, in its chairman's words, 'taken a pretty strong approach' to the question of what banks are allowed to count as tier-one capital (ASIC 2010: 14). Second, APRA (2004) has required banks making 'low documentation' housing loans to set aside additional capital. Third, APRA adopted a stringent approach in the runup to Basel II implementation in 2008 and to the new Basel III capital controls in the wake of the GFC. ${ }^{3}$ Fourth, APRA (2006) has required banks to hold additional capital against riskier aspects of banking practices, such as trading in financial assets. APRA has also insisted that banks using third-party loan originators must ensure that the credit assessment standards used by the originators match the standards of the host bank. APRA also communicates with the entire bank board, not just with senior management. It also has the power to vet and recommend against board candidates.

Successive federal governments have supported APRA's approach. Ian Harper argues that, in Australia, 'we are allowed to get on with regulation. We can distinguish between the role of the executive government and the public service. Regulators are allowed to get on with the job' (quoted in Cornell 2009).

3 The Basel capital controls require banks to hold adequate levels of capital (such as retained earnings and equity capital) on their balance sheets to help absorb losses in a downturn and help make them more resilient in a crisis. 
Littrell (2011: 5) underlines the importance of political support for the bank regulator:

Effective intervention over the necessary years and decades is impossible without broad public-sector support, most of all from politicians across the political spectrum. If you show me a country where politicians listen to the banks more than they listen to regulators, I will show you a country which is guaranteed to have a banking crisis.

\section{But did bank regulation save the Australian banks from the GFC?}

In explaining Australia's bank performance before and during the GFC, former federal treasurer Peter Costello (2009) has emphasised the strong 'regulatory and prudential arrangements that kept capital requirements strong, subprime lending low and toxic derivatives out of systemically important institutions'. It is not at all clear, however, that prudential regulation did keep 'toxic derivatives out of systemically important institutions', given the exposure (albeit limited) of two of the major banksNAB and ANZ - to such securities. Nevertheless, APRA regulated in a way that supported prudent mainstream banking and, certainly, APRA's approach was a far cry from the 'light touch' or permissive regulatory approach in the United Kingdom (Turner 2009: 86-8) and the United States (FCIC 2011: 52-66) in the runup to the GFC.

Yet effective regulation is not an explanatory panacea in this case. APRA's regulatory and supervisory effort was focused mainly on risks associated with mainstream or traditional balance sheet banking in mortgage markets and commercial lending (that is, 'normal' banking). Yet the fact that $\mathrm{NAB}$ and $\mathrm{ANZ}$ engaged in what turned out to be risky securities trading before the GFC underlines the fact that APRA did not directly seek to limit nontraditional banking through, for example, limits on proprietary trading or fixed limits on the value of derivatives banks could hold as a proportion of their total assets. Indeed, APRA was not particularly focused on US mortgage-backed securities as a source of risk. As Littrell explained in his interview, as far as exotic securities were concerned:

There wasn't a lot of analysis going into it. No-one was doing that analysis. Because everyone had essentially bought in, and I think to some extent APRA was in that camp. You know, it's AAA rated, it's well secured. All these people were saying there's absolutely no problem with it. 
The Commonwealth Bank and Westpac were more circumspect and did not buy these securities, as explained more fully below. As Littrell says: 'Some banks naturally were a bit more cautious than others.' But the fact remains that two of the major banks, supervised by APRA, did trade in these securities. As noted, NAB got into trouble and, as NAB's Alan Oster explained in his interview:

I'm sure most people didn't understand what they were doing. They just trusted the ratings agencies. So, I actually think it's a combination of a lot of things. APRA, sure, but the honest answer to me is that it had a lot more to do with the way banks operated in their environment.

Overall, then, while APRA's role as a regulator and supervisor may have helped discipline and shepherd the banks in the arena of traditional lending risk, APRA did not act as a significant and direct restraint on the kind of securities trading that compromised ANZ and NAB and that was at the centre of the GFC in overseas markets, especially in the United States and the United Kingdom. As a NAB group executive explained to us in an interview in relation to APRA's oversight of that bank's US mortgage-backed securities trading: '[W] wouldn't have been doing it if APRA had concerns about it, okay? Now, whether they understood it any more than the banks, I don't think so.'

As explained in the next section, and echoing Oster, national market structures and conditions played a much more prominent role than APRA in shaping bank behaviour in Australia, especially in relation to exposure to US mortgage-backed securities trading.

\section{National market regulation and market conditions}

Market regulation and conditions in banking and mortgage markets played a central role in keeping the Australian banks relatively safe. First, the Australian banks benefited greatly from the strong economy and a growing but largely stable mortgage market in the 1990s and 2000s. This was partly due to stabilising actions by the RBA. Second, regulation of the banks through the ban on corporate takeovers was also important.

By far the most important sources of profit for Australia’s commercial banks have been traditional commercial and mortgage lending markets. These markets have been fuelled by high levels of immigration, a China-driven 
resources boom and high rates of domestic economic growth (Debelle 2009; Jordan and Jain 2009). As the RBA's Ric Battellino (ASIC 2009: 48) has argued: 'The banks chasing profitable lending opportunities in Australia could grow their balance sheet by 15 per cent a year ... without having to take on new additional risks.' Similarly, in his interview, Saul Eslake said:

[T] he Australian banks didn't feel under any need to enhance their income or profit-generating performance by acquiring risky and, as it turned out, toxic securities in the way that US and European banks did.

Moreover, unlike in many other countries, the Australian property market, although highly inflated, did not collapse, bubble-like, and thus did not expose the banks. One factor in the stability here was a combination of sound macroeconomic management and regulation. As noted above, in the wake of the crisis and recession in the early 1990s, macroeconomic policy and the stance of the RBA were to promote growth and avoid recessions (Bell and Quiggin 2006). But the RBA was also focused on avoiding a blowout in the property market, especially after its humiliating experience in the early 1990s. This is a major example of policy learning and programmatic reassessment. The RBA had formed the view that credit and property markets were a key source of systemic risk in the financial system. During the 2000s, the RBA ran a higher interest rate policy than was the case in many other countries, especially in the United States, where interest rates were kept low after the tech stock crash and September 2001 terrorist attacks (Roubini and Mihm 2010: 73). The RBA also raised interest rates to deliberately help cool and stabilise the property market in 2003 and 2004, when a degree of overheating was apparent. In preemptively raising interest rates, the RBA was one of the few Western central banks prescient enough (and perhaps bold enough) to tackle this form of asset price inflation (Bell 2004a). The result of such actions, together with strong housing demand, helped stabilise the property market, underpin economic growth and expand the balance sheets of the banks - all of which supported strong bank profit performance in a sustainable manner.

In terms of programmatic and process assessment, the RBA's approach was largely experimental. Monetary policy is a blunt instrument and it was not clear what effects higher rates would have on credit and property markets. In terms of political assessment, the policy was risky. Although the RBA enjoyed policy independence from government, it was not 
clear whether credit and housing market interventions of this type were part of the RBA's mandate (although broader goals of financial stability were). Certainly, the Howard Government was not impressed with policy adventurism of this type and made its views known (Bell 2004a: 195). In such a context, the RBA's actions on this front were not made explicit and instead were presented as part of its normal inflation targeting (Bell 2004b; Macfarlane 2006: 112).

Other regulations were also useful in moderating mortgage credit and property markets in Australia. Unlike the United States, Australia had fullrecourse mortgages, meaning banks could pursue a loan defaulter's assets, encouraging the latter to be prudent. Nor could Australian households deduct mortgage interest payments against their tax liability, thus discouraging borrowers from maintaining a higher mortgage balance for tax reasons. Australia also has a system of uniform credit codes that impose clear legal obligations on lenders to properly assess the creditworthiness of borrowers.

Arguably, however, the most important factor in shaping bank behaviour was not traditional prudential regulation of the banks, but regulation of a different type, centred on competition policy in the banking sector. In terms of programmatic and process assessments, a particular type of competition policy in the banking sector was developed. In the early 1990s, in the face of attempted takeover activity among large financial institutions that threatened to limit competition, the federal Labor Government formulated the 'six pillars' policy, which prevented the four largest banks and the two largest insurance firms from merging. The subsequent Liberal Government removed the insurance companies from the policy, creating the 'four pillars' policy among the banks (Bakir 2005). The four pillars policy is designed to ensure market competition. By giving the four largest banks a stronger incentive to take over or merge with smaller, regionally based banks — such as BankWest (bought by the Commonwealth Bank in October 2008) and St George (bought by Westpac in November 2008) — the policy has, however, created an oligopoly among the large banks. This oligopoly has also been preserved by restrictions on the entry of foreign banks into the Australian market or the takeover of Australian banks by overseas-based operations (Barth et al. 2010: 449). 
In this context, the four pillars policy was aimed at regulating the market for corporate control in the banking sector. In so doing, it preserved competition between the big four banks, but also curtailed the banking takeover market. Ian Macfarlane (2009: 42) argues that, by reducing the threat of corporate takeovers, the four pillars policy reduced the pressure on the largest banks to protect their share price and short-term profits by engaging in 'excessive lending and risk taking'. The policy reduced competition 'to a sustainable level and thus prevented our banks from moving too far in the risky direction ... that saved us from the worst excesses that characterised banking systems overseas'. In an interview with the authors, the Commonwealth Bank's chief risk officer agreed:

[I]n a market dominated by the four major banks, none of us had compelling incentives to go down the risk curve and grow our books as much more contested markets have.

Charles Goode, former chairman of the ANZ, told us in an interview:

If you look at the countries that came through this crisis well, in a banking sense, you think of Australia, Canada, Singapore, Hong Kong and Israel. They're all countries where in domestic banking there were three or four major banks_ and really stable. So, you'll find an oligarchic structure without much international presence in domestic banking in the countries that survived.

Bell and Hindmoor (2015) show that the success of the Canadian banks in similarly avoiding the GFC stems from the same kind of regulation that structures the Australian national banking market to prevent big bank takeovers and hence moderate competition. They also show that the more intense competitive pressures and active takeover markets in banking were a key source of pressure that pushed the banks in the United States and the United Kingdom to take on extra leverage and risk in the runup to the GFC. The Australian national market structure in banking is thus very different to that found in the United States and the United Kingdom. In these two countries, successive governments have aimed to reduce barriers to competition (Claessens 2009). In the leadup to the GFC, competitive pressures shaved bank margins and profits and had the unintended effect of encouraging the banks to expand leverage and risky trading operations to sustain or boost profits. 
In Australia, however, competitive pressures were far from absent. Even within the four pillars framework, the four major banks competed for market share and profits. As Westpac's head of risk reward put it in an interview with the authors, just because four pillars 'preserves you from takeover, it doesn't stop you from competing with one another'. Hence, the local banks were interested in financial innovation and new profit opportunities. As a senior Australian banker put it in an interview with the authors: 'At the end of the day, if there are opportunities to add shareholder value at the margin, we will look at those opportunities.' Indeed, since the late 1990s and early 2000s, the local banks have invested in structured credit products, securitised domestic mortgages and used structured investment vehicles to remove mortgages from their balance sheets to economise on capital. In the runup to the GFC, the banks looked at and, in some cases, dipped into the US mortgage-backed securities market, as we have seen. In surveying the banks' attitudes to such investment, Laker recalls in his interview:

I know that at least one of the big four quite explicitly looked at this as an option and rejected it. Two of the banks looked at some involvement and had modest involvement. The fourth was not interested at all.

The two banks that rejected such investments were the Commonwealth and Westpac. The risk team at the Commonwealth Bank conveyed serious concerns about US mortgage-backed securities to senior management and to the bank's board. They concluded in an interview with us:

We really did feel that there were serious risk concerns attached to these kinds of portfolios ... We had a good look at what the true risks were and we just didn't like them ... There was a whole heap of reputational and other risks that we thought outweighed any financial benefits that might come from a little bit of extra business we might be able to book.

Edward Bosworth argues that Westpac had negative experiences with the US corporate debt market in the early 2000s amid the collapse of Enron, Worldcom and other companies. Bosworth told us in an interview that later, when US mortgage-backed securities started coming on the market, 'we applied a subjective overlay' based on the earlier experience:

We elected, by conscious decision, that it was not an appropriate strategy ... [Instead, we sought] to derive growth from our domestic market, where both subjectively and quantitatively we felt we had a better handle on the risks ... The judgement call was whether we believed we had learned sufficiently from prior experience to step back into those waters. 
The lack of or limited interest displayed by the big Australian banks reflected the fact that none had large investment banking operations. As Eslake explained in his interview: '[T]he Australian banks are commercial as distinct from investment banks and perhaps, more importantly, are run by commercial bankers as opposed to investment bankers.' This is important because, according to Ian Harper in an interview with us:

There may have been a different outcome had any of the major banks been run at the chief executive level by an investment banker rather than a traditional balance sheet banker.

In his interview, Laker argued that the Australian banks 'weren't building huge trading desks, they weren't setting up large offshore operations ... and their Treasury functions weren't doing large amounts of proprietary trading'. The banks, as Laker explained,

were really focused on growing their retail books in Australia, because that's where the opportunities were ... we have an inward-looking banking system. Our major banks are focused on growing the domestic markets ... 2005, 2006, and 2007-these were golden years for the Australian banking system doing domestic business.

Charles Goode agrees. In his interview, he told us: the 'big thing was that our economy was strong and our balance sheet didn't have problems'. Moreover, the profit returns on overseas structured credit products were small, particularly the AAA-rated and AA-rated products, which, with safe ratings, generated limited returns.

It is also the case that, unlike many overseas markets, especially in Europe, the big Australian banks were not sitting on surplus funds looking for investment opportunities. As Goode puts it: 'We had a lot of demand for lending from our normal clients within the country; you didn't have to look anywhere else.' Market structures and conditions thus provided strong incentives for banks to pursue traditional banking practices and not become heavily involved in proprietary trading or other risky behaviour in securities markets. The limited profit margins on highly rated securities, together with the costs of funding and insuring such securities, meant they were not all that attractive to the Australian banks.

Finally, in terms of political assessment, there is no doubt that in Australia the regulatory controls and market structuring that saved the Australian banks were politically popular. The public has long had a distrust of the banks and their high profits and sometimes questionable lending 
behaviour. Banking regulation has long been a feature of the Australian policy landscape, except for the 1980s, when it was (wrongfully) assumed that markets could successfully govern the system. Indeed, voters see controls over the banks as legitimate and they are thus politically sustainable in Australia. The four pillars policy is disliked by the banks, which have lobbied to retrench it, arguing they need to merge to grow in scale to become more internationally competitive. This argument has been rejected by successive governments in a political culture that also distrusts the big banks (Bakir 2005). Financial and banking regulation thus has high legitimacy in Australia. If the public had a better understanding of how the policy and market regulation and structuring of the banking sector helped steer and save the banks, the policy approach would be even more popular. Given recent banking scandals over rate fixing, assistance to money-launderers and poor customer service, more regulation is likely to be on its way.

\section{Conclusion}

This chapter has explained how bankers as interpretative, institutionalised agents operated within banks, regulatory arrangements and marketsall of which shaped banking behaviour. Overall, the behaviour of Australia's bankers produced a relatively traditional banking model that largely (although not wholly) eschewed leveraged investment strategies in the kinds of structured credit products that devastated many overseas banks. The lessons drawn from proximate institutional histories within the banks, together with the role played by APRA, may have supported a certain degree of restraint within the banks but, as argued, the regulatory structuring of markets around issues of competition and the broader dynamics of banking and mortgage markets were the most decisive influences in shaping bank behaviour in Australia. It is also the case that regulation and market dynamics broadly worked in Australia in a complementary fashion, helping to propel the banks in a mainly conservative direction.

A further lesson-especially if we compare Australia with, say, the United States-is that banking is likely to be more stable and secure if it is not exposed to major asset price bubbles in key markets. Here, an activist central bank willing to 'lean against the wind' in the face of asset price inflation can provide an important source of stability (Bell 2004b). 
Australia has thus developed a national style of banking regulation and market structuring. Prudential regulation has been strengthened but, as argued, the main form of regulation - the four pillars policy—which helped steer the banks away from excessive risk-taking, was designed not for this task, but instead to sustain banking competition by retaining the big four banks as an oligopoly. The approach limited certain forms of competition-especially in the market for corporate control—which turned out to be very beneficial. The policy outcomes in question were thus an accident - there by dent of good luck. In other words, the design of the four pillars policy was aimed not at limiting competition or stabilising risk in the banking sector. This underlines the fact that policies can sometimes have beneficial, if unintended, consequences. Luck and happenstance can matter in shaping policy success.

\section{References}

Acharya, V. and Richardson, M. 2009. 'Causes of the financial crisis.' Critical Review 21(2): 195-210. doi.org/10.1080/08913810902952903.

Australian Prudential Regulation Authority (APRA) 2004. APRA releases changes to home loan risk-weighting. Press release, 16 September. Sydney: APRA. Accessed from: www.apra.gov.au/MediaReleases/Pages/04_33.aspx (site discontinued).

Australian Prudential Regulation Authority (APRA) 2006. Implementation of the Basel II Capital Framework 6: Securitisation and the standardised approach to credit derivatives in the banking book. Discussion Paper, 13 November. Sydney: APRA.

Australian Securities and Investments Commission (ASIC) 2009. Global Crisis: The big issues for our financial markets. ASIC Summer School 2009, Sydney, 2-3 March. Available from: download.asic.gov.au/media/1311565/ASICsummer-school-report-may-2009.pdf.

Australian Securities and Investments Commission (ASIC) 2010. Securities and investment regulation: Beyond the crisis. Report, ASIC Summer School, Melbourne, 1-3 March. Available from: download.asic.gov.au/media/ 2125947/summer-school-2010.pdf.

Bakir, C. 2003. 'Who needs a review of the financial system? The case of the Wallis inquiry.' Australian Journal of Political Science 38(3): 511-34. doi.org/ $10.1080 / 1036114032000134029$. 
Bakir, C. 2005. 'The exoteric politics of bank mergers in Australia.' Australian Journal of Politics and History 51(2): 235-56. doi.org/10.1111/j.14678497.2005.00372.x.

Barth, J., Marchetti, J. and Nolle, D. 2010. 'World Trade Organization commitments versus reported practices on foreign bank entry and regulation: A cross-country analysis.' In A. Berger, P. Molynexu and J. Wilson (eds), The Oxford Handbook of Banking. Oxford: Oxford University Press.

Bell, S. 2004a. Australia's Money Mandarins: The Reserve Bank and the politics of money. Cambridge: Cambridge University Press. doi.org/10.1017/CBO 9780511550737 .

Bell, S. 2004b. 'Inflation-plus targeting at the Reserve Bank of Australia.' Australian Economic Review 37(4): 391-401. doi.org/10.1111/j.1467-8462. 2004.00340.x.

Bell, S. 2005. 'How tight are the policy constraints? The policy convergence thesis, institutionally situated actors and expansionary monetary policy in Australia.' New Political Economy 10(1): 67-92. doi.org/10.1080/13563460500031263.

Bell, S. and Hindmoor, A. 2015. Masters of the Universe, Slaves of the Market. Cambridge, MA: Harvard University Press. doi.org/10.4159/9780674425590.

Bell, S. and Keating, M. 2018. Fair Share: Competing claims and Australia's economic future. Melbourne: Melbourne University Publishing.

Bell, S. and Quiggin, J. 2006. 'Asset price instability and policy responses: The legacy of liberalisation.' Journal of Economic Issues XL: 629-50.

Carew, E. 1997. Westpac: The bank that broke the bank. Sydney: Transworld Publishers.

Claessens, S. 2009. Competition in the financial sector: Overview of competition policies. IMF Working Paper WP/09/45. Washington, DC: International Monetary Fund. Available from: www.imf.org/ /media/Websites/IMF/ imported-full-text-pdf/external/pubs/ft/wp/2009/_wp0945.ashx.

Clark, A. 2009. 'Why we are different but not necessarily safe.' Australian Financial Review, 4 December.

Colebatch, T. 2009. 'How Australia avoided the global financial meltdown (touch wood).' The Age, [Melbourne], 6 June.

Cornell, A. 2009. 'How Australia's banks dodged the crisis.' Australian Financial Review, 21 December. 
Costello, M. 2009. 'Parting thoughts of a political party's proud and fortunate son.' Sydney Morning Herald, 8 October.

Crotty, J. 2009. 'Structural causes of the Global Financial Crisis: A critical assessment of the "new financial architecture".' Cambridge Journal of Economics 33(4): 563-80. doi.org/10.1093/cje/bep023.

Davies, H. 2010. The Financial Crisis: Who is to blame? Cambridge: Polity.

Debelle, G. 2009. A comparison of the US and Australian housing markets. Address to the Sub-Prime Mortgage Meltdown Symposium, Adelaide, 16 May. Available from: www.rba.gov.au/publications/bulletin/2008/jun/pdf/ bu-0608-5.pdf.

Dodd, R. and Mills, P. 2008. 'Outbreak: US subprime contagion.' Finance and Development 45(2): 14-18.

Edwards, J. 2008. The sub-prime mortgage meltdown: Origins, trajectories and regional implications-Australia's experience in the sub-prime crisis. Address to the Flinders University International Expert Symposium, Adelaide, 16 May. Available from: treasury.gov.au/speech/the-sub-prime-mortgage-meltdownorigins-trajectories-and-regional-implications-australias-experience-in-thesub-prime-crisis/.

Erturk, I. and Solari, S. 2007. 'Banks as continuous revolution.' New Political Economy 12(3): 369-88. doi.org/10.1080/13563460701485599.

Financial Crisis Inquiry Commission (FCIC) 2011. The Financial Crisis Inquiry Report. New York: US Government Publishing Office.

Gorton, G. 2008. Slapped in the face by the invisible hand: Banking and the panic of 2007. Prepared for the Federal Reserve of Atlanta's Financial Market Conference, Atlanta, 11-13 May. Available from: www.frbatlanta.org/news/ Conferen/09fmc/gorton.pdf.

Hawtrey, K. 2009. 'The global credit crisis: Why have Australian banks been so remarkably resilient?' Agenda: A Journal of Policy Analysis and Reform 16(3): 95-114.

Jordan, C. and Jain, A. 2009. 'Diversity and resilience: Lessons from the financial crisis.' University of New South Wales Law Journal 32: 1-32.

Kelly, P. 1992. The End of Certainty: Power, politics and business in Australia. Sydney: Allen \& Unwin.

King, M. 2009. Speech to Scottish Business Organisations. Bank of England, Edinburgh, 20 October. 
Laker, J. 2006. Basel II: Observations from down under. Speech to Second Annual Conference on the Future of Financial Regulation, London School of Economics, London, 6 April.

Laker, J. 2009. The regulatory landscape 2009-2010. Speech to FINSIA Financial Services Conference, Financial Services Institute of Australasia, Sydney, 28 October.

Laker, J. 2010. The Australian banking system under stress? Speech to Australian Business Economists, Sydney, 9 June.

Lewis, D. 2008. Weathering the storm: APRA's role in financial crisis management. Speech to Business Continuity Expo, Melbourne, 27 November.

Littrell, C. 2011. Responses to the Global Financial Crisis: The Australian prudential perspective. Speech to APEC Regional Symposium, Melbourne, 8 March.

Macfarlane, I. 2006. The Search for Stability. ABC Boyer Lectures. Sydney: Australian Broadcasting Corporation.

Macfarlane, I. 2009. The crisis: Causes, consequences and lessons for the future. ASIC Summer School, Sydney, 2-3 March. Available from: download.asic. gov.au/media/1311565/ASIC-summer-school-report-may-2009.pdf.

McGee, S. 2010. Chasing Goldman Sachs. New York: Crown Business.

Reinhart, C. M. and Rogoff, K. S. 2009. This Time is Different: Eight centuries of financial folly. Princeton, NJ: Princeton University Press.

Reserve Bank of Australia (RBA) 2009. Financial Stability Review. March. Sydney: RBA.

Reserve Bank of Australia (RBA) 2010. Financial Stability Review. March. Sydney: RBA.

Ritholtz, B. 2009. Bailout Nation: How greed and easy money corrupted Wall Street and shook the world economy. New York: Wiley.

Roubini, N. and Mihm, S. 2010. Crisis Economics: A crash course in the future of finance. New York: Penguin.

Suich, M. 1991. 'Bankrupted.' The Independent Monthly, 15-17 May.

Turner, A. 2009. The Turner Review: A regulatory response to the global banking crisis. London: Financial Services Authority. 
This text is taken from Successful Public Policy: Lessons from Australia and New Zealand, edited by Joannah Luetjens, Michael Mintrom and Paul 't Hart, published 2019 by ANU Press, The Australian National University, Canberra, Australia.

doi.org/10.22459/SPP.2019.12 